\title{
Die Invloed van Otitis Media op die Sentrale Ouditiewe Vermoëns van Kinders met Sensoriese Integrasieprobleme
}

\author{
Lidia Olivier, B.Log (Pretoria) \\ Brenda Louw, D.Phil (Pretoria) \\ René Hugo, D.Phil (Pretoria) \\ Departement Spraakheelkunde en Oudiologie \\ Universiteit van Pretoria
}

\begin{abstract}
OPSOMMING
Otitis media word in die resente literatuur in verband gebring met spraak-en taalprobleme, gedragsprobleme en leerprobleme. Beperkte navorsing is egter tot op hede uitgevoer om die invloed wat otitis media op die sentrale ouditiewe vermoëns uitoefen, te bepaal. Die doel met hierdie studie is om te bepaal of otitis media wel 'n invloed op die sentrale ouditiewe vermoëns van kinders met sensoriese integrasieprobleme uitoefen. Dertien persone wat gediagnoseer is as kinders met sensoriese integrasieprobleme, is as proefpersone geselekteer. Hulle is in twee grotpe' ingedeel, naamlik agt proefpersone met' $n$ geskiedenis van otitis media (Groep A) en vyf proefpersone sonder 'n $n$ geskiedenis van otitis media (Groep B). ' $n$ Toetsbattery is saamgestel vir die evaluering van die sentrale ouditiewe vermoëns en is op die proefpersone uitgevoer. In die geval van groep $A$ was die resultate afuzkend in elke subtoets in die sentrale toetsbattery wat op 'n moontlike breinstambetrokkendheid dui. Groep B het normale resultate in bykans al die toetse verkry. Die resultate dui daa rop dat chroniese otitis media wel 'n invloed op die sentrale ouditiewe vermoëns van die proefpersone het en wel in terme van onvoldoende breinstamfunksionering. Implikasies vir navorsing en behandeling is bespreek.
\end{abstract}

\section{ABSTRACT}

In recent literature otitis media is linked to speech and language problems, behavioural problems and learning disabilities. Until recently limited research has been done in order to determine the influence of otitis media on the central auditory abilities. The aim of this study was to determine whether otitis media has an influence on the central auditory abilities of children with sensory integration problems. Thirteen persons diagnosed as children with sensory integration problems were selected as subjects. They were divided into two groups, namely eight subjects with a history of otitis media (group A) and five subjects without a history of otitis media (group B). A test battery was compiled for evaluation of the central auditory abilities and was used on the subjects. In terms of group A deviating results were obtained on every subtest of the central auditory test battery which indicated a possible brainstem involvement. Group B obtained normal results in more or less all the tests. The results therefore suggest that chronic otitis media has an influence on the central auditory abilities, i.e. in terms of insufficient brainstem functioning. Implications for research and treatment were discussed.

Otitis media is tans 'n populêre navorsingsonderwerp, hoofsaaklik as gevolg van die omvattende invloed wat dit op die kind kan uitoefen (Gottlieb, Zinkus \& Thompson, 1979).

Dwarsdeur die literatuur word otitis media in verband met spraak- en taalprobleme, gedragsprobleme en leerprobleme gebring (Gottlieb et al. 1979). Alhoewel otitis media ook in verband gebring word met die sentrale ouditiewe vermoëns, is daar tot op hede nog beperkte navorsing in hierdie verband uitgevoer. In die lig daarvan dat die sentrale ouditiewe vermoëns' $n$ belangrike rol in sensoriese integrasie speel, en deur 'n verband tussen otitis media en sentrale ouditiewe prosessering te bepaal, kan nuwe inligting, oor veral die invloed van otitis media, maar ook die rol van die oudioloog by die kind met sensoriese integrasieprobleme, beskikbaar gestel word.

Otitis media is ' $n$ kindersiekte met' $n$ baie hoë voorkoms, veral by kinders van ses jaar en jonger (McShane \& Mitchell, 1979). Teenstrydighede ten opsigte van die invloed van otitis media op kinders kom egter lin die literatuur voor en navorsingsbevindinge kan hoofsaaklik in twee groepe verdeel word
(Paradise, 1983). Die eerste groep navorsers toon aan dat kinders wat wel'n geskiedenis van otitis media het, maar van wie die gehoor normaal was tydens toetsing, geen of slegs 'n geringe agterstand toon in terme van sintaksis, taalbegrip, leesvermoë en woordeskat (Owrid, 1970). Die tweede groep navorsers het bevind dat otitis media wel'n negatiewe invloed op taalontwikkeling, veral in terme van taalinhoud en -vorm het (Blager, 1982; Sak \& Rubin, 1982).

Volgens Paradise (1983) kan hierdie geskilpunt in die literatuur verklaar word uit leemtes in die navorsing. Diagnose van otitis media in vroeëre lewensjare is ten eerste nie baie betroubaar nie. Tydens toetsing vertoon sommige proefpersone otitis media en kan daar dus nie akkurate inligting met betrekking tot hulle ontwikkeling bekom word nie. Slegs beperkte steekproewe is gewoonlik gebruik en die betroubaarheid van die studies word in baie gevalle betwyfel (Paradise, 1983).

As daar egter in gedagte gehou word dat otitis media soms gepaard gaan met'n geringe konduktiewe gehoorverlies, is dit 'n logiese afleiding dat dit wel 'n invloed op die normale ont- 
wikkelingsverloop van die kind moet uitoefen. Die negatiewe sekondêre gevolge van otitis media kan verklaar word op grond van die wisselende graad vari ouditiewe deprivasie wat ondervind word. Studies het aangetoon dat die eerste vyf lewensjare veral belangrik is vir breinmaturasie (Webster, 1983). Die eerste vier lewensjare is ook die kritieke periode van taalaanleer (Rubin, 1984). Dit is in hierdie tyd, maar veral gedurende die eerste twee lewensjare dat otitis media by kinders voorkom (Northern \& Downs, 1984).

Gehoor is noodsaaklik vir die ontwikkeling van die ouditiewe bane in die perifere en sentrale ouditiewe sisteem. 'n Fluktuerende konduktiewe verlies as gevolg van otitis media kan 'n negatiewe invloed op die ontwikkeling van die ouditiewe funksie, sowel as op kognitiewe en kommunikasievaardighede uitoefen (Hornsby, 1984). Die ontwikkeling van ouditiewe prosessering word ook nadelig beinvloed deur otitis media, aangesien die ouditiewe boodskappe nie die sentrale senuweestelsel akkuraat bereik nie (Zinkus, 1982). Afwykings in sentrale prosessering, versteuring in ouditiefvisuele integrasie, leesprobleme en ouditiewe persepsieprobleme word dus in verband gebring met die herhaaldelike. voorkoms van otitis media (Gottlieb, 1979; Zinkus, 1982). Webster (1983) is ook eens dat 'n chroniese konduktiewe gehoorverlies in die vroeë lewensjare tot 'n permanente sentrale ouditiewe afwyking kan lei. Otitis media kan dus ' $n$ invloed op die sentrale ouditiewe vermoëns van kinders uitoefen.

Die ouditiewe sisteem, en in die besonder die sentrale ouditiewe sisteem, is veral in die geval van kinders met sensoriese integrasieprobleme van belang as 'n sensoriese modaliteit vir die persepsie van ouditiewe invoer. Normaalweg word die sensoriese inligting, afkomstig van die ouditiewe sisteem, met die sensoriese invoer van ander sensoriese modaliteite, naamlik die vestibulêre sisteem, taktiele sisteem, propriosepsie en die visuele sisteem geïntegreer sodat daar toepaslik daarop gereageer kan word. Die interpretasie en integrasie, asook toepaslike reaksie op sensoriese stimuli, staan bekend as sensoriese integrasie. Die proses word deur die sentrale senuweestelsel teweeggebring deurdat 'n massa sensoriese inligting gefiltreer, georganiseer en geïntegreer word, sodat dit gebruik kan word in die ontwikkeling en uitvoering van die brein se funksies (Ayres, 1973). 'n Wanfunksie ten opsigte van sensoriese integrasie beteken dat die vloei van sensoriese inligting deur middel van die sensoriese modaliteite nie voldoende geprosesseer en georganiseer word nie. Sodoende kan die individu nie presiese inligting oor homself en sy wêreld beleef nie (Ayres, 1973). Dit strem die individu in die ontwikkeling van hoër breinfunksies en kan, onder andere, tot die volgende simptome lei: hiperaktiwiteit; afleibaarheid; gedragsprobleme; spierwankoördiniasie; taal- en spraakprobleme, asook leerprobleme.

Navorsing toon egter dat sensoriese integrasieprobleme tot leerprobleme kan lei en in baie gevalle nou verwant is aan leerprobleme (Ayres, 1973). Baie van die simptome van kinders mét sensoriese integrasieprobleme stem ooreen met die simptome van leergestremde kinders, bv. ouditiewe prosesseringsprobleme, asook verskeie uitvalle ten opsigte van taalfunksies (Ayres, 1973). In die geval van kinders met leerprobleme word hierdie probleme veral in verband gebring met die simptome en gevolge van otitis media. Zinkus (1982) dui ook aan dat kinders met leerprobleme 'n hoër voorkoms van otitis media $(25-36 \%)$ as normale kinders $(13-17 \%)$ toon, veral as hulle probleme verwant is aan ouditiewe vaardighede. Aangesien otitis media wel 'n invloed op kinders met leerprobleme het, en wel veral in terme van hulle sentrale ouditiewe vermoëns, kan daar verwag word dat otitis media ook'n invloed kan hê op die sentrale ouditiewe vermoëns van kinders met sensoriese integrasieprobleme.

Die bepaling van die verband tussen otitis media en die sentrale ouditiewe vermoëns kan nuwe lig op die etiologie en simptomatologie van sensoriese intregrasieprobleme asook op die implikasies van otitis media werp. Insluiting van die oudioloog in die span wat die kind met sensoriese integrasieprobleme hanteer, kan tot voorkoming van die nadelige invloed van otitis media op die sentrale ouditiewe vermoëns, en gevolglik die algehele funksionering van die kind, lei.

\section{METODE}

\section{Doel}

Die doel van die studie is om die invloed van otitis media op die sentrale ouditiewe vermoëns van kinders met sensoriese integrasieprobleme te bepaal deur:

- die sentrale ouditiewe vermoëns van twee groepe kinders met sensoriese integrasieprobleme, naamlik die met en die sonder 'n geskiedenis van otitis media te peil

- intergroepsooreenkomste en -verskille tussen die twee eksperimentele groepe te bepaal.

- intragroepsooreenkomste en -verskille tussen die proefpersone in elke eksperimentele groep te bepaal.

\section{Navorsingsontwerp}

'n Beskrywende navorsingsplan is gebruik aangesien dit intraen intergroepsvergelyking, waarvolgens die gestelde navorsingsvrae beantwoord kan word, moontlik maak (Steyn et al. 1984).

\section{Proefpersoonseleksie}

Die proefpersone het dertien kinders met sensoriese integrasieprobleme ingesluit. Die dertien proefpersone is met behulp van 'n vraelys geselekteer uit die totale aantal Afrikaanssprekende kinders met sensoriese integrasieprobleme wat terapie ontvang by 'n privaat arbeids' en spraakterapiekliniek. Agt kinders met'n geskiedenis van otitis media (Groep A) en vyf sonder' $n$ geskiedenis daarvan (Groep B) is op 'n eenvoudige ewekansige wyse geselekteer.

Die proefpersone moes oor normale perifere gehoor beskik en tussen die ouderdomme 6 en 10,5 jaar wees.

Tabei 1 verskaf 'n opsommende weergawe van die kenmerke van die proefpersone. 
Tabel 1: Algemene beeld van proefpersone wat in hierdie ondersoek ingesluit is

\begin{tabular}{|c|c|c|c|c|c|c|}
\hline Eksperimentele groep & Proefpersoon & Geslag & Ouderdom & \multicolumn{2}{|c|}{ Gemiddelde gehoordrempel } & Timpanogram \\
\hline Groep A & & & & L & $\mathrm{R}$ & \multirow{9}{*}{$\begin{array}{l}\text { Normale tipe } A^{*} \\
\text { Normale tipe A } \\
\text { Normale tipe A } \\
\text { Normale tipe A } \\
\text { Geen sluiting }{ }^{+} \\
\text {Normale tipe A } \\
\text { Normale tipe A } \\
\text { Normale tipe A }\end{array}$} \\
\hline Kinders met sensoriese & 1 & V & $8 \mathrm{j} \quad$ Omnde & $0 \mathrm{~dB}$ & $0 \mathrm{~dB}$ & \\
\hline integrasieprobleme met & 2 & $\mathrm{M}$ & $7 \mathrm{j} 5 \mathrm{mnde}$ & $13,3 \mathrm{~dB}$ & $10 \mathrm{~dB}$ & \\
\hline 'n geskiedenis van & 3 & M & $9 \mathrm{j} 9$ mnde & $5 \mathrm{~dB}$ & $3,3 \mathrm{~dB}$ & \\
\hline otitis media & 4 & $M$ & $6 \mathrm{j} 4 \mathrm{mnde}$ & $6,6 \mathrm{~dB}$ & $6,6 \mathrm{~dB}$ & \\
\hline$\therefore$ & 5 & M & $6 \mathrm{j} 4 \mathrm{mnde}$ & $10 \mathrm{~dB}$ & $11,6 \mathrm{~dB}$ & \\
\hline & 6 & V & $6 \mathrm{j} 10$ mnde & $0 \mathrm{~dB}$ & $0 \mathrm{~dB}$ & \\
\hline & 7 & M & $7 \mathrm{j} 2$ mnde & $3,3 \mathrm{~dB}$ & $3,3 \mathrm{~dB}$ & \\
\hline & 8 & V & $7 \mathbf{j} 1 \mathrm{mnd}$ & $0 \mathrm{~dB}$ & $0 \mathrm{~dB}$ & \\
\hline \multicolumn{7}{|l|}{ Groep B } \\
\hline \multirow{5}{*}{$\begin{array}{l}\text { Kinders met sensoriese } \\
\text { integrasieprobleme } \\
\text { sonder 'n geskiedenis } \\
\text { van otitis media }\end{array}$} & 9 & M & $9 j 6$ mnde & $0 \mathrm{~dB}$ & $3,3 \mathrm{~dB}$ & Normale tipe $A$ \\
\hline & 10 & $\mathrm{~V}$ & $7 \mathrm{j} 5 \mathrm{mnde}$ & $8,3 \mathrm{~dB}$ & $3,3 \mathrm{~dB}$ & Normale tipe $A$ \\
\hline & 11 & $\mathrm{M}$ & $6 \mathrm{j} 6$ mnde & $0 \mathrm{~dB}$ & $0 \mathrm{~dB}$ & Normale tipe $A$ \\
\hline & 12 & V & $8 \mathrm{j} 11 \mathrm{mnde}$ & $0 \mathrm{~dB}$ & $0 \mathrm{~dB}$ & Normale tipe $A$ \\
\hline & 13 & M & $10 j 6$ mnde & $8,3 \mathrm{~dB}$ & $8,3 \mathrm{~dB}$ & Normale tipe A \\
\hline
\end{tabular}

* Normale timpanogram - dit wil sê normale "compliance" en middeloordruk.

+ Geen sluiting verkry. Het reeds 22 maal buisies in beide ore gekry.

\section{PROSFDURE}

\section{Data-insameling}

'n Volledige gehoorevaluasie is op elke proefpersoon uitgevoer. Vir hierdie doel is ' $n$ GSI- 10 oudiometer en 33 Middle Ear Analizer gebruik asook Telephonics TDH-50 oorfone met MX41/AR kussings. Die oudiometer is op 1989-01-10 gekali-

\section{Tabel 2: Sentrale Ouditiewe Sisteem Toetsbattery}

\begin{tabular}{|c|c|c|c|}
\hline \multicolumn{2}{|r|}{ Toets } & \multicolumn{2}{|r|}{ Motivering vir insluiting by toetsbattery } \\
\hline A & Perifere gehoorevaluasie: & & \\
\hline 1 & Suiwertoontoetsing & 1 & $\begin{array}{l}\text { Normale perifere gehoor is 'n voorvereiste vir die uit- } \\
\text { voering van sentrale ouditiewe toetse (Musiek, 1985). }\end{array}$ \\
\hline 2 & Spraakontvangsdrempel & 2 & $\begin{array}{l}\text { Word as basis gebruik waarvolgens die intensiteit vir aan- } \\
\text { bieding van ander toetsstimuli bepaal is. }\end{array}$ \\
\hline 3 & Spraakdiskriminasie in stilte & 3 & $\begin{array}{l}\text { Deur middel van die bepaling van spraakdiskriminasie in } \\
\text { stilte by 4-5 intensiteite is die FG-PI-funksies (Fonetiesge- } \\
\text { balanseerde woordelysprestasie-intensiteitsfunksie) be- } \\
\text { paal, om dit te kan vergelyk met die SS1-PI-funksie (Sinte- } \\
\text { tiese sinsidentifikasieprestasie-intensiteitsfunksie) om tot } \\
\text { differensiaaldiagnose by te dra. }\end{array}$ \\
\hline 4 & Timpanometrie & 4 & $\begin{array}{l}\text { 'n Objektiewe meting van middeloorfunksie om die moont- } \\
\text { likheid van middeloor-betrokkenheid uit te skakel. }\end{array}$ \\
\hline B & Toetse vir Sentrale ouditiewe prosessering & & \\
\hline 5 & Akoestiese refleksdrempelbepaling & 5 & $\begin{array}{l}\text { Vergelyking van ipsilaterale en kontralaterale reflekse ver- } \\
\text { skaf waardevolle inligting vir moontlike identifikasie van } \\
\text { breinstamletsels (Hall, 1985). }\end{array}$ \\
\hline 6 & Sintetiese sinsidentifikasie (SSI) SSI-PI & 6 & $\begin{array}{l}\text { SSI-PI versus FG-PI verskaf inligting vir 'n differen- } \\
\text { siaaldiagnose tussen kogleare- retro-kogleare-en sentrale } \\
\text { ouditiewe senuweestelselletsels (Jerger \& Hayes, } 1977 \text { in } \\
\text { Rintelman, 1985). }\end{array}$ \\
\hline & SSI-IKB (ipsilaterale kompeterende boodskap & & $\begin{array}{l}\text { Differensieer verder tussen sentrale letsels (breinstam ver- } \\
\text { sus temporale lobletsels). }\end{array}$ \\
\hline 7 & $\begin{array}{l}\text { Maskeringsvlakverskiltoets (MVV-toets) } \\
\text { - met suiwertone as stimulus } \\
\text { - met spondeewoorde as stimulus }\end{array}$ & 7 & $\begin{array}{l}\text { Verskaf inligting oor laer breinstamfunksionering (Noff- } \\
\text { singer et al. 1985). }\end{array}$ \\
\hline 8 & $\begin{array}{l}\text { Simultaneous Binaural Median-Plane Localization } \\
\text { Test (SBMPL-Test) I }\end{array}$ & 8 & Verskaf inligting oor algemene breinstamfunksionering. \\
\hline
\end{tabular}

breer en voldoen aan die vereistes van SABS 0154-1979. Die eksperimentele toetsbattery was daarop gemik om die sentrale ouditiewe sisteem te evalueer en word in Tabel 2 verskaf. 


\section{DATA-ANALISE}

Response van die proefpersone is deurentyd op toetsvorms aangeteken. Die data is daarna in terme van die volgende kriteria beoordeel:

\section{Akoestiese reflekse}

Die akoestiese reflekse is beoordeel in terme van: normaal, verhoog, afwesigen verlaag. Indien die akoestiese refleks (ipsilateraal en kontralateraal) tussen 80-100 dBSP voorgekom het, is dit as normaal beskou (Fria et al. 1985 en Metz, 1946 in Northern et al. 1985). Enige refleks wat hoër as $100 \mathrm{~dB}$ intree, is as 'n verhoogde refleks beskou en enige refleks laer as $60 \mathrm{~dB}$ as 'n verlaagde refleks.

\section{Sintetiese-sinsidentifikasietoets}

Die SSI-PI-funksie versus die FG-PI-funksie is beoordeel in die lig van Jerger \& Hayes se kriteria (Rintelman, 1985). Die resultate van die SSI-IKB en SSI-KKB is volgens die kriteria van Jerger \& Jerger (1975) soos aangedui deur Musiek en Pinheiro (1975) beoordeel.

\section{Maskeringsvlakverskiltoets}

Die resultate van die Maskeringsvlakverskiltoets is in terme van afwykend en normaal beoordeel. Die normale maskeringsvlakverskilwaarde by $500 \mathrm{~Hz}$, dit wil sê, die verskil in drempelwaardes met aanbieding van die toetsstimuli in (0/0)en uit (0/180)-fase is $10-15 \mathrm{~dB}$ (Noffsinger et al. 1985). ' $n$ Vermindering in die maskeringsvlakverskilwaarde, dit wil sê, minder as $10 \mathrm{~dB}$ word as afwykende resultate beskou.

Simultaneous Binaural Median-Plane Localization Test

Twee beoordelings is gemaak, naamlik normaal of afwykend. Die vermoë om die klank waar te neem met.'n interourale intensiteitsverskil van $0-10 \mathrm{~dB}$ is beskou as normale resultate. Onvermoë om die klank sentraal waar te neem of sentrale waarneming van die klank met groot interourale-intensiteitsverskille, dit wil sê, groter as $10-15 \mathrm{~dB}$ is as afwykende resultate beskou (Jerger, 1960).

Resultate

Resultate word bespreek in dieselfde volgorde as wat die toetsbattery uitgevoer is.

\section{AKOESTIESE REFLEKSE Ipsilaterale \& Kontralaterale reflekse}

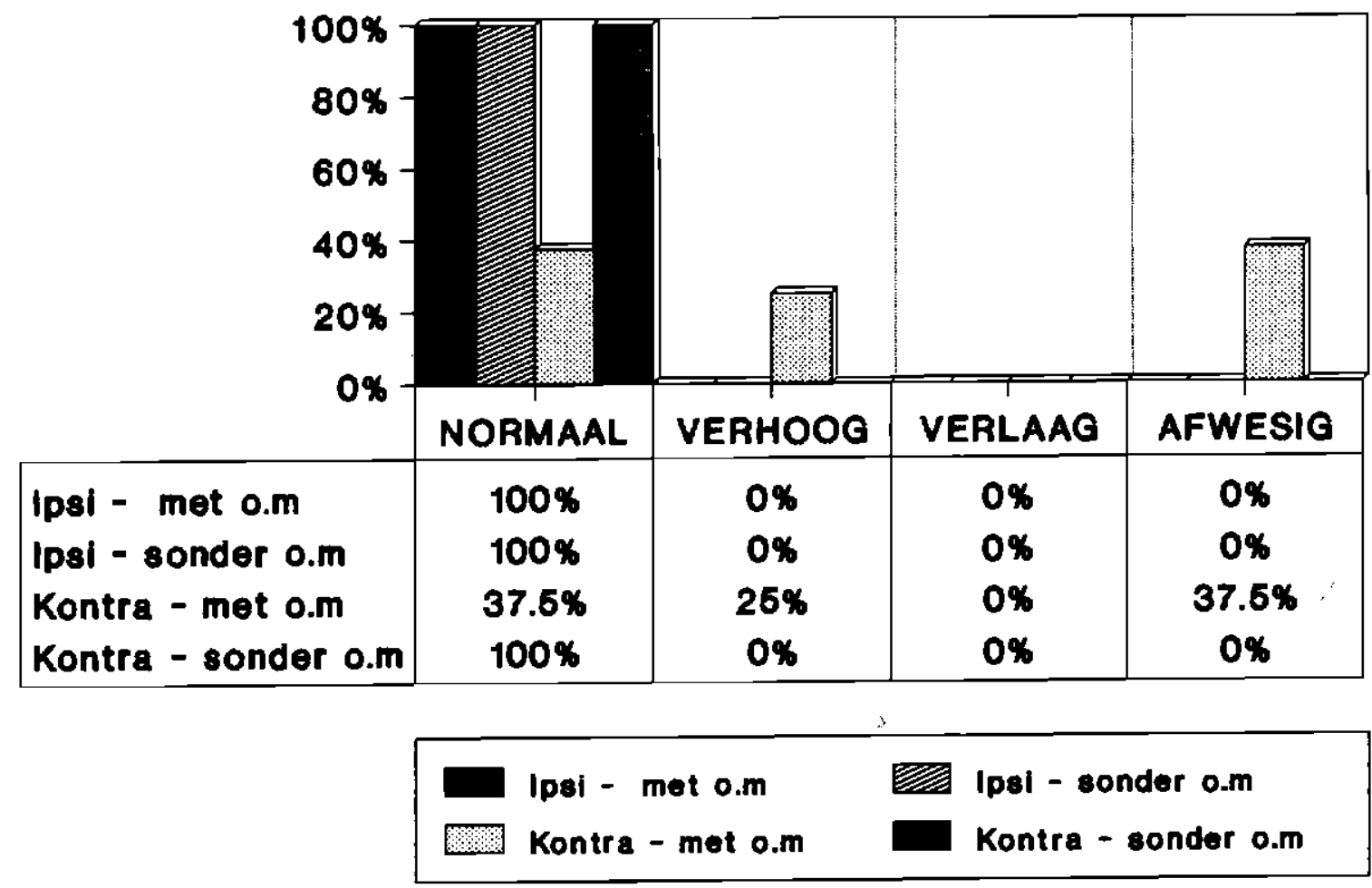

\section{Figuur 1}

Figuur 1: Staafkaart van Akoestiese Reflekse

In figuur 1 word die ipsilaterale en kontralaterale refleksresultate uiteengesit. Dit blyk duidelik uit die voorstclling dat Groep A en B normale ipsilaterale, reflekse vertoon het.
In terme van die kontralaterale reflekse hét groep A normale, verhoogde en afwesige kontralaterale reflekse vertoon. In geval van groep B het normale kontralaterale reflekspatrone voorgekom. 
Sintetiese sinsidentifikasietoets (SSI)

In hierdie geval is twee metings gemaak, naamlik:

- 'n vergelyking tussen die FG-PI-funksie en die SSI-PIfunksie

- vergelyking van SSI resultate in die teenwoordigheid van 'n ipsilaterale kompeterende boodskap asook 'n kontralaterale kompeterende boodskap.

\section{FG-PI versus -PI}

Die gemiddelde van die resultate word aangetoon in figure $2 a$ en $2 b$.

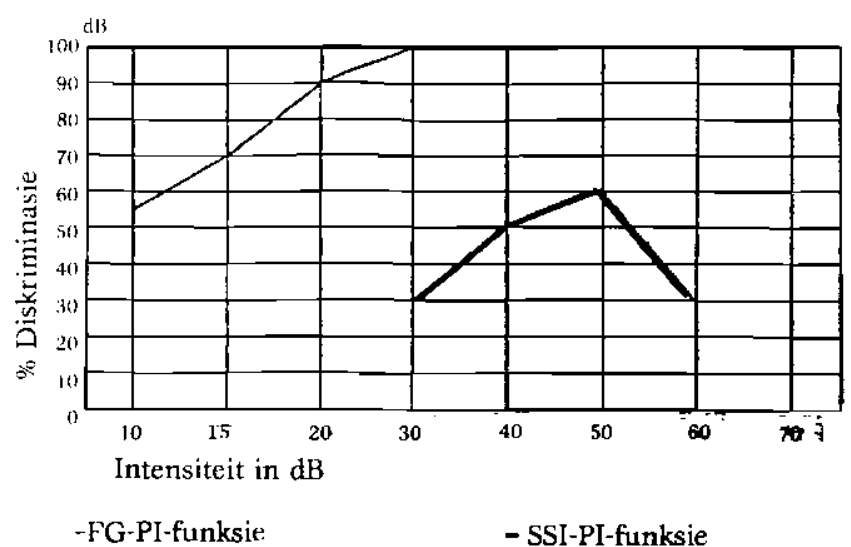

Figuur 2(a): SSI-PI-funksie versus FG-PI-funksie: Groep A

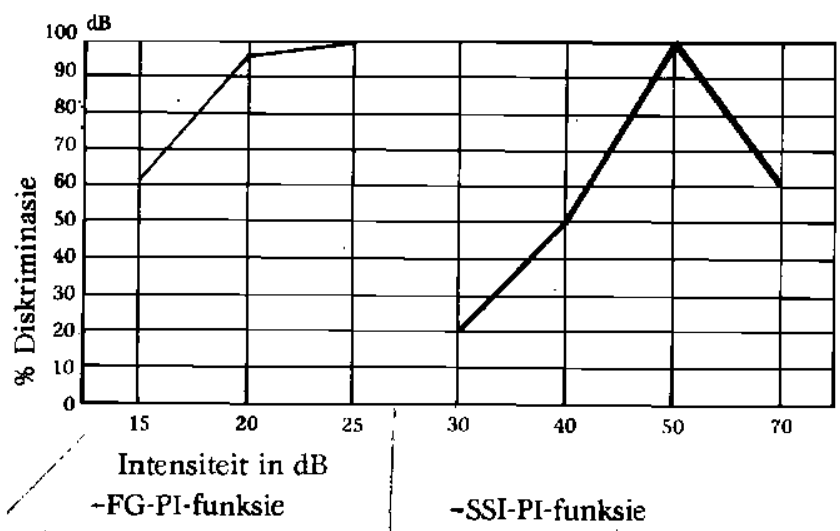

Figuur 2(b): SSI-PI-funksie versus FG-PI-funksie: Groep B

Figuur 2(a) toon dat die proefpersone in groep A se resultate op die FG-PI-funksie binne normale perke was. Die spraakdiskriminasievermoëns van die proefpersone het telkens $100 \%$ gebly met 'n verhoging in intensiteit nadat die persentasie maksimum korrekte spraakdiskriminasie bereik is. Die SSI-PIfunksie is heelwat swakker en verloop onder die FG-PI-funksie. Dit vertoon ook telkens 'n sogenaamde "roll-over" (Jerger en Hayes, 1977 in Tintelman, 1985).

Groep Bvertoon afwykende resultate (figuur 2(b)) van die SSIPI-funksie in die sin dat die SSI-PI-funksie onder die FG-PIfunksie verloop en telkens 'n sogenaamde "roll-over" vertoon (Jerger \& Hayes, 1977 in Rintelman, 1985). Hierdie resultate is egter in 'n mindere mate afwykend in vergelyking met groep A se resultate. In geval van groep B was die FG-PI-funksie ook binne normale perke.

\section{SSI-PI versus SSI-KKB}

Die resultate van die SSI-IKB word deur die volgende figure voorgestel.

Die Suid-Afrikaanse 7ydskrif vir Kommunikasieafwykings. Vol. 37, Ibu

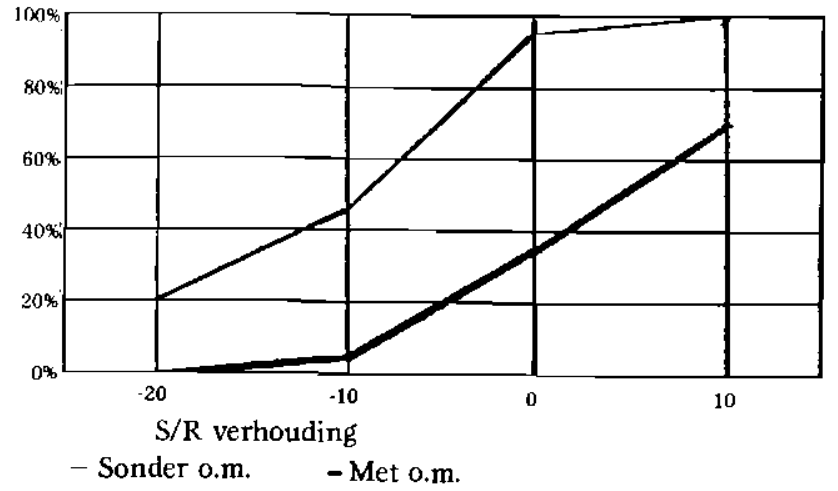

Figuur 3(a): Resultate van SSI-IKB (links)

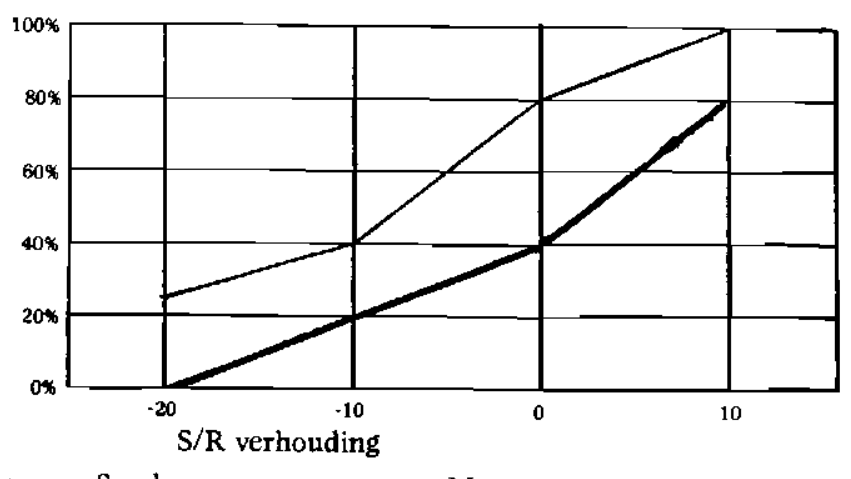

- Sonder 0.m.

- Met o.m.

Figuur 3(b): Resultate van SSI-IKB (regs)

Uit hierdie figure is dit duidelik dat beide groep A en B afwykende resultate vertoon het. Groep A se resultate is egter in 'n meerdere mate afwykend in vergelyking met die van groep B.

\section{Maskeringsvlakverskiltoets}

Figuur 4 is 'n voorstelling van die resultate wat in die Maskeringvlakverskiltoets vir suiwertone en spraak verkry is.

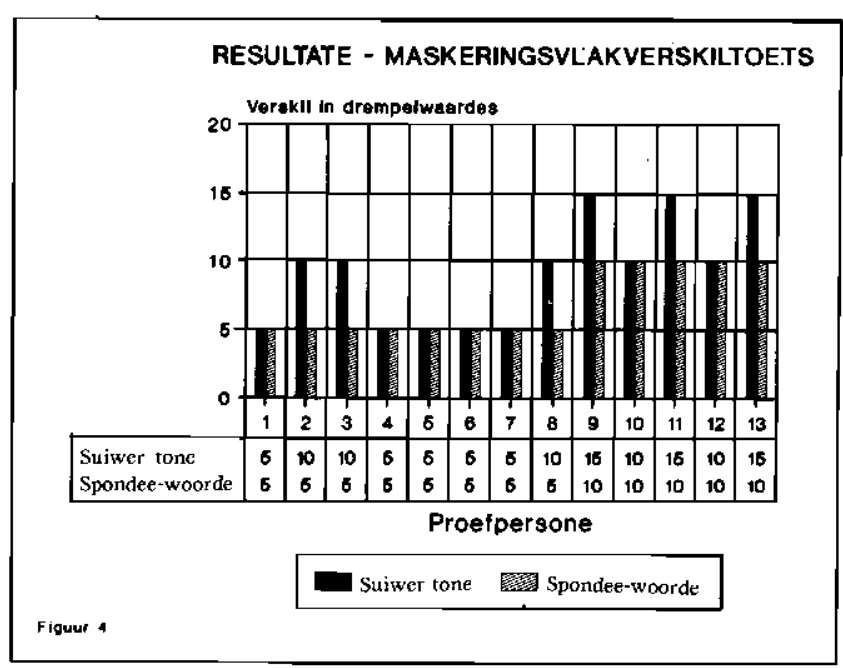

Figuur 4: Resultate van die Maskeringsvlakverskiltoet 
Dit blyk dat daar in terme van beide die suiwertoon-en spraakstimuli afwykende resultate by al die proefpersone in groep $\mathrm{A}$ verkry is. Hulle resultate is afwykend aangesien die verskil in responsdrempels wat verkry is by die aanleiding van die toetsstimuli en die kompeterende boodskap in fase $\left(0^{\circ} / 0^{\circ}\right)$ en uit fase $\left(0^{\circ} / 180^{\circ}\right) 10 \mathrm{~dB}$ en minder was. Normale response is by groep B verkry, dit wil sê die verskil in responsdrempels met die aanbieding van die suiwertoon- en spraakstimuli en die kompeterende boodskap in en uit fase was $10 \mathrm{~dB}$ en meer.

Simultaneous Binaural Median-Plane Localization Test Figuur 5 is 'n voorstelling van die resultate wat verkry is.

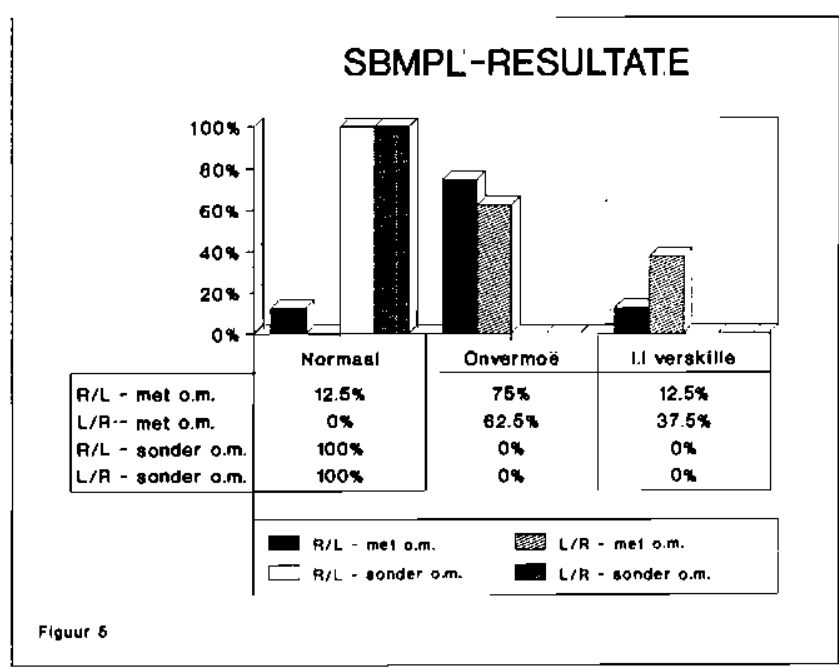

Figuur 5: Resultate van die SBMPL-toets

Uit hierdie voorstelling blyk dit dat die proefpersone van groep A se resultate in 'n groot mate van die van groep B verskil. Groep $A$ het meestal 'n onvermoë getoon om die klank sentraal waar te neem of dit is wel sentraal waargeneem met groot interourale intensiteitsverskille. Groep B se resultate was heeltemal normaal.

\section{BESPREKING VAN RESULTATE}

Dit wil voorkom asof die eksperimentele vraag of herhaaldelike otitis media in die vroeë lewensjare 'n invloed op die sentrale ouditiewe vermoëns van persone met sensoriese integrasieprobleme uitoefen, deur die verkreë resultate beantwoord is. Uit die resultate blyk dit duidelik dat daar in die geval van groep A, die proefpersone met 'n geskiedenis van otitis media, oor die algemeen swakker resultate in die sentrale ouditiewe toetsbattery gelewer het in vergelyking met groep $B$ wat bestaan het uit proefpersone sonder 'n geskiedenis van otitis media.

In terme van die akoestiese refleksmeting dui verskeie outeurs (Northern et al. 1985; Griessen \& Rasmussen 1970 in Hall, 1985) aan dat afwesige of verhoogde kontralaterale reflekse met gepaardgaande normale ipsilaterale reflekse 'n aanduiding van breinstampatologie is.

Dit blyk dus dat die proefpersone in Groep A se resultate 'n aanduiding van moontlike breinstampatologie kan wees. Volgens Northern et al. (1985) kan dit verklaar word op grond van die teenwoordigheid van 'n letsel of wanfunksionering in die area waar die breinstambane kruis. Die ongekruisde bane bly intakt en het dus normale ipsilaterale reflekse tot gevolg. In die geval van die proefpersone in groep B (proefpersone sonder ' $n$ geskiedenis van otitis media) was die resultate deurgaans normaal.

Die resultate van die akoestiese refleksmeting word deur die SSI-toetsbattery geverifieer. Die resultate van die FG-PI-funksie versus die SSI-PI-funksie dui daarop dat die FG-PI-funksie se resultate in geval van die proefpersone in beide groep $A$ en $B$ binne normale perke geval het. Die SSI-PI-funksie het in die geval van die proefpersone in groep A, asook in die van groep B, onder die FG-PI-funksie verloop en 'n sogenaamde "roll-over" vertoon. Die proefpersone in groep A se prestasie in die SSI-PIfunksie was egter heelwat swakker as die van die proefpersone in groep B.

Jerger \& Hayes (1977) in Rintelman (1985) het bevind dat, indien die SSI-PI-funksie onder die FG-PI-funksie verloop, dit 'n aanduiding van 'n sentrale afwyking in die kontralaterale oor is. In hierdie studie was die resultate afwykend in beide ore van al die proefpersone in groepe A en B. Die teenwoordigheid van 'n sentrale betrokkenheid by die vergelyking van die SSI-PI-funksie en die FG-PI-funksie dui egter nie die spesifieke area van wanfunksionering aan nie.

In die geval van die SSI-IKB versus SSI-KKB dui die resultate daarop dat die SSI-KKB in die geval van al die proefpersone binne normale perke was. Met betrekking tot die ipsilaterale kompeterende boodskap (SSI-IKB) het al die proefpersone afwykende resultate vertoon. Net soos in die geval van die FGPI-funksie versus die SSI-PI-funksie was die resultate van die proefpersone in groep $A$ in ' $n$ meerdere mate afwykend in vergelyking met die van die proefpersone in groep $\mathrm{B}$. Jerger (1981) het aangetoon dat in die geval van kinders met onvoldoende breinstamfunksionering die prestasie in die SSI-KKB binne normale perke val, terwyl die SSI-IKB afwykende resultate vertoon. In die verband verklaar Jerger \& Jerger (1974): "For brainstem patients, the SSI procedure shows poor performance of ICM and relatively good performancerfor CCM. The ICM deficits are observed on the contralateral ear and CCM performance is within normal limits on both ears." (1974, p. 342).

Wat interessant is, is dat die proefpersone in groep B met betrekking tot die SSI-toetsbattery swakker gepresteer het. Toetsresultate met betrekking tot die res van die sentrale toetsbattery was binne normale perke. Die swakker prestaśie in die SSI-toetsbattery kan in die lig van die volgende verklaar word: Kinders met normale gehoor leer taal aan éerstens deur die ouditiewe sisteem. Lees is 'n sekondêre taalvaardigheid wat afhanklik is van visueel-ouditiewe integrasie in die breinstam, soos gevind in studies van Birch \& Belmont, Kahn \& Birch \& Bartholomeus en Doehring in 1976 (Musiek \& Pinheiro, 1985). Kinders met sensoriese integrasieprobleme ondervind probleme met visuele-ouditiewe integrasie. Volgens Ayres (1983) speel die breinstam 'n sentrale rol in normale sensoriese integrasie. Die breinstam organiseer alle sensoriese informasie deur middel van inhibisie, fasilitasie en sintese om sodoende ' $n$ volledige interpretasie van alle sensoriese stimuli te maak. Dit help die brein orm op een tipe sensoriese invoer te fokus, terwyl die res geïnhibeer word. In die geval van die SSI-toetsbattery was nie net al die proefpersone se vermoë om die visuele stimuli met die ouditiewe stimuli te integreer, aangetas nie, maar ook die vermoë om die primêre stimuli te kan isoleer deur middel van inhibering van moontlike waarneming van die kompeterende bóodskap. Laasgenoemde twee aspekte is volgens Ayres (1983) kenmerkend van kinders met 
sensoriese integrasieprobleme en dit kan dus 'n bydraende faktor wees tot die swakker prestasie in die SSI-toetsbattery in hierdie studie.

Laastens wat die SSI-toetse betref, moet daarop gewys word dat die proefpersone in groep A se prestasie in die SSI-toetsbattery swakker was as die van die proefpersone in groep $B$. Dit kan waarskynlik die gevolg wees van die herhaalde otitis media in die vroeë lewensjare wat moontlik 'n invloed op breinstamfunksionering gehad het.

Die maskeringvlakverskiltoets bevestig ook die bevindinge tot dusver. Die proefpersone in groep A se resultate was afwykend in geval van beide die suiwertoon-en spraakstimuli in die sin dat die responsdrempels wat verkry is by die aanbieding van die toetsstimuli en kompeterende boodskap in fase $\left(0^{\circ} /\right.$ $\left.0^{\circ}\right)$ en uit fase $\left(0^{\circ} / 180^{\circ}\right), 10 \mathrm{~dB}$ en minder was. Normale response deur die proefpersone in groep B is verkry, dit wil sè die verskil in responsdrempels met die aanbieding van die suiwertoon- en spraakstimuli en die kompeterende boodskap in en uit fase was $10 \mathrm{~dB}$ en meer. Volgens verskeie outeurs soos Sweetow \& Reddel (in Willeford, 1985) hou die Maskeringsvlakverskiltoets belowende resultate in indien 'n breinstamafwyking vermoed word tydens die toetsing van leergestremde kinders. Die Maskeringsvlakverskiltoets se resultate in hierdie studie bevestig ook die moontlikheid van 'n breinstamletsel of onvoldoende breinstamfunksionering. Aangesien daar geen ander veranderlikes as otitis media was nie, kan daar'n korrelasie tussen die voorkoms van otitis media en die afwykende resultate op die Maskeringsvlakverskiltoets bepaal word.

Bogenoemde resultate word verder bevestig deur die SBMPLtoetsresultate wat ook op 'n algemene breinstamdisfunksie dui. Die proefpersone in groep A was nie in staat om die klank sentraal waar te neem nie; of die klank is sentraal waargeneem met groot interourale-intensiteitsverskille (meer as $10 \mathrm{~dB}$ ) Stephens (1976) het gevind dat persone met 'n breinstamletsel afwykende resultate in die SBMPL-toets toon.

In die lig van die verkreë resultate in die sentrale toetsbattery blyk dit duidelik dat daar'n moontlike breinstamletsel of wanfúnksionering in die geval van die proefpersone in groep A voorkom. Aangesien die proefpersone in groep B se resultate op die sentrale ouditiewe toetsbattery (met uitsluiting van die SSI-toetsbattery) binne normale perke was, ontstaan die vraag waarom die proefpersone in groep $A$ dan beduidend swakker presteer het op die toetsbattery. Aangesien otitis media die enigste veranderlike is wat die twee eksperimentele groepe onderskei, noodsaak dit 'n diepgaande ondersoek na die moontlike rol wat otitis media in' die sentrale ouditiewe gehoorvermoëns kan speel, veral met betrekking tot breinstamfunksionering.

Verskeie menings oor die rol van otitis media in die sentrale ouditiewe vermoëns van leergestremde kinders, word in die literatuur voorgehou. Gottlieb et al. (1979) toon 'n duidelike verband aan tussen otitis media en die sentrale ouditiewe vermoëns, asook die visuele integrasievermoëns van leergestremde kinders. Volgens Zinkus (1982) toon verskeie leergestremde kinders sentrale ouditiewe probleme in bv reeksgeheue; diskriminasie en sluiting. Dit is die gevolg van onvoldoende prosessering van ouditiewe invoer, alhoewel die kind se kognitiewe funksie intakt is. Identifikasie, diskriminasie en organisasie wat die basis van die ouditiewe leerproses vorm, kan dus in die geval van hierdie kinders afwykend wees. Johnson (1981) meen dat leergestremde kinders met sentrale ouditiewe prosesseringsprobleme ook hoërisiko-gevalle is vir otitis media. Die fluktuerende gehoorverlies wat tydens periodes van otitis media voorkom, het dus moontlik 'n beplande invloed op die sentrale ouditiewe vermoëns van die leergestremde kind (Zinkus, 1982). Die fluktuerende gehoorverlies lei tot onvoldoende ouditiewe invoer tydens die vroeë lewensjare. Aangesien die vroeë lewensjare die kritieke tyd is vir spraak- en taalontwikkeling, asook vir maturasie van, onder andere, die ouditiewe sisteem, is dit logies om tot die gevolgtrekking te kom dat otitis media wel'n invloed op die maturasie van die ouditiewe sisteem het. Dit kan lei tot latere onvoldoende ouditiewe prosessering wat die grondslag van sentrale ouditiewe probleme vorm. Die moontlike invloed wat otitis media in die sentrale ouditiewe vermoëns kan speel, word verder toegelig deur diere-eksperimente. Studies deur Webster en Webster (1977, in Zinkus, 1982) toon dat 'n konduktiewe gehoorverlies tydens kritieke periodes van breinmaturasie tot morfologiese veranderinge in sekere neurone van die ouditiewe nuklei kan lei. Volgens Webster (1983) is die ouditiewe sisteem afhanklik van omgewingsinvoer en kan daar dus duidelik strukturele veranderinge plaasvind as gevolg van'n chroniese konduktiewe gehoorverlies in die vroeë lewensjare. In'n studie met muise is ook aangetoon dat ' $n$ herhaaldelike konduktiewe gehoorverlies tydens kritieke postnatale periodes tot anatomiese en fisiologiese veranderinge in die breinstam lei.

Volgens Katz \& Wilde (1985) het verskeie navorsers ook tot soortgelyke gevolgtrekkings oor die invloed van otitis media op die sentrale ouditiewe sisteem gekom (Holm \& Kunze, 1969; Northern \& Downs, 1978; Rubin \& Rapin, 1980). Dit blyk dus duidelik uit die literatuur dat die herhaaldelike konduktiewe gehoorverlies wat tydens chroniese otitis media voorkom, 'n invloed op die maturasie van veral die breinstam en uiteindelik op die sentrale ouditiewe gehoorvermoëns het. Katz \& Wilde (1985) is dit ook eens dat die sogenaamde ouditiewe deprivasie-effek die mees logiese verklaring is vir die uiteindelike langtermyninvloed wat otitis media op die sentrale ouditiewe vermoëns het. Sensoriese deprivasie speel uiteindelik 'n bydraende rol in terme van afwykende vermoëns in die organiser ing en strukturering van inligting (Ayres, 1983). Voldoende stimuli is beskikbaar, maar onvoldoende prosessering vind plaas, aangesien die struktuur wat noodsaaklik is vir optimale prosessering nie voldoende ontwikkel het nie as gevolg van sensoriese deprivasie tydens kritieke stadia van ontwikkeling. Indien hierdie studie se resultate in verband met bogenoemde verklaring gebring word, kan die gevolgtrekking gemaak word dat die proefpersone in groep A se swakker prestasie in die sentrale toetsbattery moontlik te wyte is aan vroeë ouditiewe deprivasie wat veroorsaak is deur otitis media. Die sensoriese deprivasie kon gelei het tot ònvoldoende maturasie van veral die breinstam soos gemanifesteer in die verkreë resultate van die studie.

Die resultate van hierdie studie het dus nie net op die korrelasie van otitis media en die sentrale ouditiewe probleme van die proefpersone in groep Agedui nie, maar veral op die korrel. sie tussen otitis media en die breinstamfunksionering van die proefpersone in groep A. Volgens Zinkus (1982) kan chroniese otitis media egter nie gesien word as die enigste oorsaak van alle sentrale ouditiewe probleme nie. Die etiologie van sentrale probleme kan dikwels nie gedefinieer word nie.

Katz \& Wilde (1985) toon aan dat al hoewel tumors en ander sentrale letsels in kinders kan voorkom, sentrale ouditiewe toetse by kinders meestal uitgevoer word in die lig van moontlike ouditiewe prosesserings- of leerprobleme. I)ie doel met 
sentrale toetsing by kinders is dus nie om die lokus van 'n letsel te bepaal nie, maar eerder om die funksionering en maturasie van die verskillende dele van die sentrale ouditiewe sisteem te evalueer. In die lig van hierdie studie bevestig die verkree resultate laasgenoemde stelling deurdat daar aangetoon is dat herhaaldelike otitis media wel 'n invloed het op die sentrale ouditiewe vermoëns van proefpersone met sensoriese integrasieprobleme en wel in terme van onvoldoende breinstam funksionering.

\section{GEVOLGTREKKINGS EN AANBEVELINGS}

Alhoewel die steekproef van hierdie studie beperk was, dui die resultate daarop dat chroniese otitis media wel 'n invloed het op die sentrale ouditiewe vermoëns van kinders met sensoriese integrasieprobleme. Die resultate wat met die sentrale toetsbattery by die proefpersone met ' $n$ geskiedenis van otitis media verkry is, dui op afwykende resul tate met betrekking tot die sentrale ouditiewe vermoëns, en wel in terme van onvoldoende breinstamfunksionering. In die geval van die proefpersone sonder geskiedenis van otitis media, is normale resultate in al die toetse verkry, behalwe in geval van die SSI-toetsbat- tery waar geringe afwykende resultate deur die proefpersone vertoon is. Laasgenoemde resultate kan egter verklaar word in die lig van die visueel-ouditiewe integrasieprobleme wat kinders met sensoriese integrasieprobleme ondervind. In terme van intragroepkorrelasies het die sentrale toetsbattery se resultate nie gedui op 'n beduidende verskil tussen prestasie van manlike en vroulike proefpersone in die toetsbattery nie. 'n Groter steekproef kan moontlik geslagsverskille aan die lig bring.

Vanuit'n kliniese oogpunt blyk die resultate van hierdie studie veral van belang te wees. Daar word nie net inligting oor die invloed van otitis media op die sentrale ouditiewe vermoëns van kinders met sensoriese integrasieprobleme beskikbaar gestel nie, maar ook inligting oor die rol van die oudioloog by die kind met sensoriese integrasieprobleme. Insluiting van die oudioloog in die multidissiplinêre span wat die kind met sensoriese integrasieprobleme hanteer, kan deur vroeë identifikasie en suksesvolle intervensie tot die voorkoming van die nadelige invloed van otitis media lei.

\section{VERWYSINGS}

Ayres, A.J. Sensory integration and the child. Ios Angeles: Western Psychological Services, 1973.

Ayres, A.J. Sensory integration and learning disorders. Los Angeles: Western Psychological Services, 1983.

Blager, F.B. "The effect of otitis media on speech and language development". Seminars in Speech. Language and Hearing, 3, 313$320,1982$.

Gottlich, M.E., Zinkus, P.W.\& Thompson, M.A. "Chronic middle-ear disease and auditory perceptual deficits". Clinical Pediatrics, 18(12), 725-732, 1979

Hall, J.W. "Ihe acoustic reflex in central auditory dysfunction. In Pinheiro, M.L. \& Musiek, F.E. (ed.): Assessment of Central Auditory Dysfunction foundations and clinical correlates. Baltimore: Williams and Wilkens, 1985.

Hornsby, B. Overcoming dystexia. Kenwyn. Juta and Co., Ltd., 1984

Jerger, J.F. "Observations on auditory behaviour in lesion of central auditory pathways." Archives of Otolaryngology. 77, 797-806, 1960 .

Jerger, J.F. \& Jerger, S. "Auditory findings in brain-stem disorders." Archives of Otolaryngology, 99, 342:349, 1974.

Jerger, J.F. \& Jerger S. Auditory disorders - a manual for clinical evaluation. Boston. Little Brown Inc., 1981.

Jerger, S. Evaluation of central auditory function in children. In Keith, R.W. (ed.): Central Auditony and l, anguage Disorders in Children. Houston: College Hill Press, 1981.

Johnson, D.J. Considerations in the assessment of central auditory disorders in learning disabled children. In Keith. R.W. (ed.): Cen tral Auditory and Language Disorders in Children. Houston: College Hill Press, 1981.

Kat7. J. \& Wilde. I. Auditory perceptual disorders in children. In Katz. J. (cd.): Clinical Handbook of Audiology. Baltimore: Williams \& Wilkins, 1985.

McShane, D. \& Mitchell, J. "Middle ear disease, hearing loss and educational problems of American Indian children." Journal of Americun Indian Education, 7-11, 1979

Musiek, F.M. \& Pinheiro, M.L. Dichotic Speech Tests in the detection of central auditory dysfunction. In Pinheiro. M.L. \& Musiek. F.E. (eds.): Assessment of Central Auditoru I) usfunction - Foundations and Clinicul Correlates. Baltimore; Williams \& Wilkens, 1975 .
Noffsinger, D., Martinez, C.D. \& Schaefer, A.B. Puretone techniques in cvaluation of central auditory function. In Katz, J. (ed.) Handbook of Clinical Audiology. Baltimore, Williams \& Wilkens, 1985.

Northern, J.I. \& Downs, M.P. Hearing in Children. Baltimore: Williams \& Wilkens, 1984.

Northern, J.I. Gabbard, S.A. \& Kinder, D.I. The acoustic reflex. In Katz, J. (ed.): Handbook of Clinical Audiology. Baltimore: Williams \& Wilkens, 1985.

Owrid, H.L. "Hearing impairment and verbal attainment in primary school children." Education Research, 12, 209-214, 1970.

Paradise, J.L. "Long term effects of short term hearing loss-Menace or Myth?" Pediatrics, 71, 647-648, 1983.

Rintelman, W.F. Monaural Speech 'l'ests in the Detection of Central! Auditory Disorders. In Pinheiro, M.I. \& Musiek, F.E. (ed.): Assessment of Central Dysfunction - Foundations and Clinical Cor- ; relates. Baltimore: Williams \& Wilkens, 1985 .

Rubin, R.J. "The effects of recurrent middle ear effusion in pre-school years on language and learning." Audiology in Práctice, 1 (Supplement 3), 5-7, 1984.

Sak, R.J. \& Ruben, R.J. "Effects of recurrent middle ear effusion in preschool years on language and learing." Journal of Developmental and Behavioural Pediatrics, 3, 7-77, 1982.

Stephens, S.D.G. \& Thornton, A.R.D. "Subjective and Electrophysiologic tests in Brainstem lesions". Archives of Otolaryngology, $102,608-612,1976$.

Webster, D.B. Effects of peripheral hearing losses on the audiotry brainstem. In Lasky, E.Z. \& Katz, J. (ed.): Contral Auditory Processing Disorders - of Speech. Language and Learning. Baltimore: University Park Press, 1983.

Willeford. J.A. Sentence tests of central auditory dysfunction. In Katz, J. (ed.): Handbook of Clinical Audiology. Baltimore; Williams \& Wilkens, 1985.

Zinkus, P.W. "Psychoeducational and sequelae of chronic otitis media." Seminars in Speech, Language and Hearing, 3, 305. 312. I982. 